\title{
KAJIAN ETNOBOTANI ZINGIBERACEAE SEBAGAI BAHAN PENGOBATAN TRADISIONAL ETNIS BATAK TOBA DI SUMATERA UTARA
}

\author{
(Ethnobotany of Zingiberaceae as A Traditional Herbal Medicine of Batak Toba Ethnic \\ in North Sumatera)
}

\author{
JAMILAH NASUTION ${ }^{1 *}$, RIYANTO ${ }^{1)}$ DAN RADIANSYAH HADI CHANDRA ${ }^{1)}$ \\ 1) Fakultas Biologi, Universitas Medan Area, Indonesia 33172
}

*Email: jamilah.nasution83@gmail.com

Diterima 22 November 2019 / Disetujui 28 April 2020

\begin{abstract}
Zingiberaceae is a family of plant species that has medicinal usefulness and is widely used by Batak Toba ethnic as traditional medicine. Therefore, this research aims to find out the species of Zingiberaceae that have been used as traditional herbal medicine the Batak Toba ethnic. This research is a qualitative-descriptive study through an emic and ethic approach. The method used is semi-structural and open-ended interviews. The results showed nine species of the Zingiberaceae used in traditional medicine by Batak Toba; there are as follow: Zingiber officinale, Zingiber purpureum, Zingiber americanus, Curcuma domestica, Curcuma xanthorhiza, Alpinia galanga, Kaempferia galanga, Etlingera elatior, and Amomum compactum. The plant parts that are used are stems, fruits, and rhizomes. The utilization of Zingiberaceae based on percentage is divided into three groups: $60 \%$ for medical treatment, $25 \%$ for health-cares, and $15 \%$ for health.
\end{abstract}

Keywords: Batak Toba Ethnic, ethnobotany, traditional herbal medicine, zingiberaceae

\section{ABSTRAK}

Zingiberaceae merupakan salah satu famili dari jenis tumbuhan yang berkhasiat obat dan banyak dimanfaatkan oleh etnis Batak Toba sebagai bahan obat tradisional. Oleh karena itu, tujuan penelitian ini adalah untuk mengetahui jenis-jenis dari suku Zingiberaceae yang dimanfaatkan sebagai bahan pengobatan tradisional oleh etnis Batak Toba. Penelitian ini bersifat deskriptif kualitatif melalui pendekatan emik dan pendekatan etik. Metode yang digunakan adalah wawancara bersifat semi struktural yang dilakukan secara terbuka (open-ended). Hasil penelitian menunjukkan sembilan jenis dari suku Zingiberaceae digunakan dalam pengobatan tradisional oleh etnis Batak Toba yaitu Zingiberofficinale, Zingiber purpureum, Zingiber americanus, Curucuma domestica, Curcuma xanthorhiza, Alpinia galanga, Kaempferia galanga, Etlingera elatior, dan Amomum compactum. Bagian tumbuhan yang dimanfaatkan adalah rimpang, daun dan batang. Pemanfaatan Zingiberaceae berdasarkan persentase hasil wawancara diperoleh 3 kelompok, yaitu untuk pengobatan $60 \%$, perawatan $25 \%$, dan kesehatan $15 \%$.

Kata kunci: Batak Toba, etnobotani, pengobatan tradisional, zingiberaceae.

\section{PENDAHULUAN}

Studi tentang hubungan antara manusia dengan tumbuhan atau tanaman adalah domain etnobotani. Etnobotani mempelajari peranan manusia dalam memahami hubungannya dengan lingkungan tempat mereka tinggal. Dalam konteks hubungan manusia dengan alam, pada dasarnya lingkungan alam menyediakan sumber daya yang dapat dimanfaatkan oleh penghuninya untuk kelangsungan hidup. Etnobotani adalah ilmu yang mengungkapkan keterlibatan sistem kebudayaan terhadap interaksi manusia dengan tumbuhan yang berada di lingkungannya. Interaksi tersebut merupakan cara pandang masyarakat dalam mengkarakterisasi, mengelompokkan dan memanfaatkan tumbuhan (Walujo 2011).

Sumatera Utara merupakan salah satu provinsi multietnis. Etnis asli yang berasal dari Sumatera Utara adalah Batak, Nias dan Melayu. Etnis Batak sebagai suku asli dan merupakan citra dari Sumatera Utara yang terdiri dari beberapa sub-etnis yaitu Toba, Karo, Mandailing, Simalungun, Angkola dan Pakpak. Etnis Batak Toba merupakan etnis yang sangat memegang teguh tradisi warisan nenek moyang, baik yang diwariskan secara lisan maupun tulisan. Salah satunya adalah pengetahuan tentang pemanfaatan tumbuhan yang berpotensi sebagai obat oleh masyarakat etnis Batak Toba yang menjadi warisan leluhur secara turuntemurun.

Kabupaten Humbang Hasundutan adalah salah satu daerah yang memiliki masyarakat dengan mayoritas etnis Batak Toba. Kabupaten Humban Hasundutan terdiri dari 10 kecamatan yaitu Bakti Raja, Dolok Sanggul, Lintong Nihuta, Onan Ganjang, Pakkat, Paranginan, Parlilitan, Pollung, Sijama Polang, dan Tara Bintang (BPS 2018).

Sejak zaman dahulu, masyarakat Batak Toba sudah mengenal obat-obatan tradisional yang beranekaragam dengan berbagai manfaat. Obat-obatan tradisional tersebut diperoleh langsung dari alam dan diolah secara sederhana berdasarkan pengalaman dan pengetahuan yang dimiliki oleh masyarakat (Handayani 2015). 
Zingiberaceae atau dikenal dengan tumbuhan jahejahean banyak dimanfaatkan oleh etnis Batak Toba sebagai bahan obat tradisional. Selain itu, tumbuhan jahe-jahean dimanfaatkan sebagai bahan rempah-rempah yang menjadi bahan campuran dalam masakan. Zingiberaceae mempunyai banyak jenis yang sebagian besar jenisnya mudah dikembangbiakkan serta berkhasiat secara turun temurun dalam mengobati berbagai penyakit. Oleh karena itu, diperlukan data untuk pendokumentasian jenis-jenis tumbuhan dari suku Zingberaceae yang digunakan sebagai bahan pengobatan tradisional oleh etnis Batak Toba di Sumatera Utara.

Beberapa penelitian terdahulu mengungkapkan jenis-jenis tumbuhan yang berkhasiat obat oleh etnis Batak Toba, antara lain (Anggraeni 2016), menyatakan bahwa masyarakat etnis Batak Toba di Desa Peadungdung memanfaatkan 92 jenis tumbuhan yang berpotensi sebagai obat, enam jenis di antaranya adalah tumbuhan yang berasal dari famili Zingiberaceae; Ibo dan Arimukti (2019) di Desa Martoba menyebut 98 jenis tumbuhan yang dimanfaatkan sebagai obat oleh etnis Batak Toba, empat jenis di antaranya merupakan tumbuhan dari famili Zingiberaceae; dan Hutagalung (2016), terdapat 108 jenis tumbuhan obat yang dimanfaatkan oleh masyarakat suku Batak Toba di Kampung Pagaran Lambung, dan sebagian besar termasuk famili Zingiberaceae. Menurut Silalahi et al. (2013) terdapat 152 spesies 64 famili jenis tumbuhan yang dikenal oleh masyarakat sub etnis Batak Karo untuk mengobati 21 jenis penyakit. Di antara jenis tumbuhan tersebut, Zingeberaceae (11 spesies) merupakan famili yang paling banyak digunakan dibandingkan dengan jenis lainnya seperti, Poaceae (7spesies) dan Lamiaceae (7 spesies). Terkait dengan latar belakang di atas, tujuan penelitian adalah untuk mengetahui jenis-jenis tumbuhan dari famili Zingiberaceae yang selalu digunakan etnis Batak Toba sebagai bahan pengobatan tradisional.

\section{METODE PENELITIAN}

Penelitian dilakukan di Desa Sipituhuta, Kecamatan Pollung, Kabupaten Humbang Hasundutan pada Oktober sampai dengan Desember 2018. Bahan yang gunakan dalam penelitian ini adalah jenis tumbuhan yang berasal dari famili Zingiberaceae, yang memiliki potensi sebagai obat dan sering dimanfaatkan oleh masyarakat Batak Toba. Jenis penelitian ini merupakan penelitian deskriptif kualitatif melalui pendekatan emik dan pendekatan etik. Pendekatan emik dimaksud untuk mendapatkan data mengenai pengetahuan masyarakat tentang jenis-jenis Zingiberaceae menurut pengetahun dan bahas mereka, sedangkan pendekatan etik digunakan untuk menganalisis data pengetahuan tersebut secara ilmiah.
Metode dalam penelitian ini menggunakan wawancara semi struktur yang berpedoman pada daftar pertanyaan sebagai panduan untuk mengajukan pertanyaan kepada responden, dan dilakukan secara terbuka (open-ended). Wawancara dilakukan kepada masyarakat etnis Batak Toba yang dianggap memiliki pengetahuan lebih luas seperti dukun/tabib, tokoh adat, dan tokoh masyarakat tentang jenis tumbuhan yang digunakan sebagai bahan pengobatan tradisional masyarakat Batak Toba. Penentuan responden menggunakan metode purposive sampling yang bertujuan untuk pengambilan data informasi tentang pemanfaatan Zingiberaceae yang dipilih secara sengaja oleh peneliti.

Data yang dikumpulkan merupakan data primer yang berasal dari 20 orang informan (dukun/tabib, tokoh adat, dan tokoh masyarakat) yang dianggap lebih mengenal dan paling sering memanfaatkan tumbuhan sebagai bahan pengobatan khususnya jenis-jenis tumbuhan Zingiberaceae. Kemudian data yang diperoleh dipersentasekan untuk melihat berapa banyak pemanfaatan Zingiberaceae menurut masyarakat Etnis Batak Toba.

$\%$ Pemanfaatan $=\frac{\text { Jumlah responden (kelompokmanfaat) }}{\text { Jumlah total responden }} \times 100 \%$

\section{HASIL DAN PEMBAHASAN}

Hasil penelitian yang telah dilakukan, diperoleh sembilan jenis tumbuhan dari suku Zingiberaceae yang digunakan sebagai bahan pengobatan tradisional oleh Etnis Batak Toba di Sumatera Utara. Jenis-jenis tersebut adalah Zingiber officinale (jahe), Zingiber purpureum (bungle), Zingiber americans (leppuyang), Curucuma domestica (kunyit), Curcuma xanthorhiza (temulawak), Alpinia galanga (lengkuas), Kaempferia galanga (kencur), Etlingera elatior (kecombrang), dan Amomum compactum (kapulaga) (Tabel 1).

Tabel 1 menunjukkan bahwa jenis-jenis tumbuhan yang berasal dari suku Zingiberaceae memiliki manfaat yang beragam dan selalu digunakan oleh etnis Batak Toba sebagai bahan pengobatan tradisional. Salah satu manfaat Zingiberaceae adalah sebagai obat masuk angin dan obat batuk. Selain itu, Zingiberaceae juga sering digunakan untuk pemberi aroma atau bumbu masakan sehingga tumbuhan ini biasanya selalu tersedia di rumah. Hal ini berkaitan dengan lokasi tempat tinggal masyarakat berada di dataran tinggi yang identik dengan cuaca dingin sehingga membuat masyarakat mudah masuk angin dan juga bermanfaat sebagai penghangat tubuh dan pengobatan yang mudah dikembangkan serta berkhasiat secara turun temurun dalam mengobati berbagai penyakit. 
Tabel 1 Jenis tumbuhan dari famili Zingiberaceae dan manfaatnya sebagai bahan pengobatan tradisional oleh etnis Batak Toba

\begin{tabular}{|c|c|c|c|c|}
\hline \multirow{2}{*}{ No } & \multirow{2}{*}{ Genus } & \multicolumn{2}{|c|}{ Nama jenis } & \multirow[t]{2}{*}{ Manfaat } \\
\hline & & Nama ilmiah & Nama lokal & \\
\hline 1 & Zingiber & Zingiber officinale & Jahe & $\begin{array}{l}\text { Sebagai penghangat tubuh, mengobati demam, } \\
\text { dan bisul. }\end{array}$ \\
\hline 2 & & Zingiber purpureum & Bungle & Untuk perawatan kehamilan dan persalinan \\
\hline 3 & & Zingiber americanus & Lempuyang/Leppuyang & Sebagai penambah stamina dan nafsu makan \\
\hline 4 & Curcuma & Curcuma domestica & Kunyit/Hunik & $\begin{array}{l}\text { Sebagai penambah stamina dan nafsu makan, } \\
\text { mengobati demam berdarah, diare, maag, serta } \\
\text { mengobati penyakit khusus kewanitaan }\end{array}$ \\
\hline 5 & & Curcuma xanthorizha & Temulawak & $\begin{array}{l}\text { Untuk melancarkan buang air besar dan } \\
\text { mengobati penyakit ginjal. }\end{array}$ \\
\hline 6 & Alpinia & Alpinia galanga & Lengkuas & $\begin{array}{l}\text { Untuk mengobati penyakit kulit (panu dan } \\
\text { kurap), batuk dan mengobati bau badan. }\end{array}$ \\
\hline 7 & Kaempferia & Kaempferia galanga & $\begin{array}{l}\text { Kencur/ } \\
\text { Kaciwer }\end{array}$ & $\begin{array}{l}\text { Untuk mengobati batuk, penyakit kulit (gatal- } \\
\text { gatal), dan untuk perawatan kehamilan dan } \\
\text { persalinan. }\end{array}$ \\
\hline 8 & Etlingera & Etlingera elatior & Kecombrang & $\begin{array}{l}\text { Membersihkan darah kotor pasca melahirkan } \\
\text { dan melancarkan ASI. }\end{array}$ \\
\hline 9 & Aтотит & Amomum compactum & Kapulaga & $\begin{array}{l}\text { Untuk mengobati batuk dan melancarkan } \\
\text { saluran pencernaan. }\end{array}$ \\
\hline
\end{tabular}

Menurut penelitian (Nasution 2009) menyatakan bahwa jenis tumbuhan Zingiber officinale, Zingiber purpureum, Zingiber americans, Alpinia galanga, dan Kaempferia galanga merupakan komponen utama sebagai bahan perawatan kesehatan ibu pasca melahirkan yang diramu dalam ramuan Oukup oleh Eetnis Karo. Penelitian Shanthi et al. (2014) menyatakan bahwa variasi ramuan dan jenis tumbuhan yang paling banyak digunakan untuk perawatan ibu hamil dan pasca melahirkan. Menurut Kuntorini (2018) terdapat tujuh jenis anggota famili Zingiberaceae dalam pengobatan tradisional oleh masyarakat Banjarbaru, yaitu Alpinia galanga, Curcuma domestica, Curcuma xanthorrhiza, Kaempferia galanga, Zingiber officinale, Kaempferia pandurata, dan Curcuma aeruginosa. Masing-masing jenis memiliki manfaat yang berbeda-beda berdasarkan pengelompokkan pengobatan penyakitnya yaitu pengobatan jenis penyakit gangguan pernafasan, demam, penyakit dalam dan menetralkan darah.

Bagian tumbuhan yang digunakan sebagai bahan pengobatan sebagian besar adalah rimpangnya. Selain itu batang, bunga dan biji juga merupakan bagian tanaman yang sering digunakan. Cara pengobatan yang dilakukan berbeda-beda yaitu direbus atau dibuat jamu dan diambil airnya untuk diminum, diambil sarinya dengan cara diparut kemudian diminum airnya atau dioleskan pada bagian tubuh yang diobati seperti bagian kulit (bisul, panu, kurap dan gatal-gatal), perut, kening atau bagian lainnya dan ada juga yang langsung dimakan misalnya rimpang Zingiber officinale yang berfungsi sebagai penghangat tubuh. Peramuan sederhana ini diyakini bahwa sari tumbuhan yang diramu sudah keluar dari bagian tumbuhan sehingga lebih mudah dalam mengolahnya dan hasilnya lebih efektif dalam proses pengobatan.

Menurut Susiarti (2015); Purwanti (2016) peramuan jenis tumbuhan dilakukan secara sederhana yaitu dengan cara bagian tumbuhan yang dimanfaatkan cukup dengan cara direbus. Bagian tumbuhan yang dimanfaatkan yaitu daun, kulit kayu, batang, akar dan buah. Selain itu, pengolahan dengan cara direbus sangat mudah dan hemat karena bisa direbus hingga berulang kali.

Berdasarkan hasil persentase pemanfaatan jenis Zingiberaceae sebagai bahan pengobatan oleh masyarakat etnis Batak Toba diperoleh tiga kelompok yaitu pengobatan, perawatan, kesehatan (Gambar 1). Gambar 1 menunjukkan bahwa kelompok pengobatan memiliki persentase yang lebih besar (60\%) dibanding dengan kelompok perawatan (25\%) dan kesehatan (15\%). Hal ini menyatakan bahwa masyarakat Batak Toba meyakini jenis-jenis tumbuhan yang berada dekat di sekeliling mereka dan mereka kenali memiliki potensi sebagai bahan pengobatan tradisional yang mudah dijumpai dan diolah untuk proses pengobatan. 


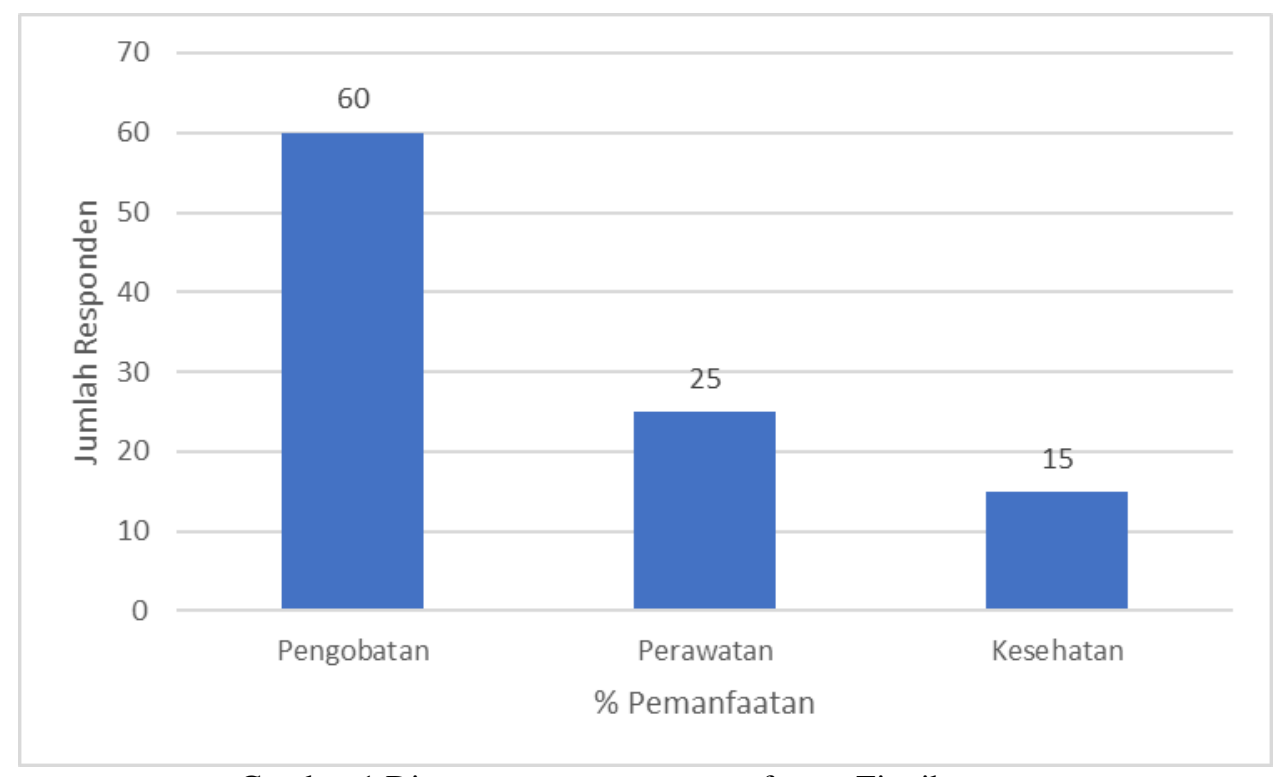

Gambar 1 Diagram persentase pemanfaatan Zingiberaceae

Pengobatan dengan menggunakan obat-obatan tradisional yang memiliki latar belakang budaya masyarakat tertentu disebut dengan pengobatan tradisional. Hal ini dilakukan dengan cara dikelompokkan sebagai teknologi tepat guna karena bahan-bahan yang digunakan terdapat di sekitar masyarakat sehingga mudah didapat, murah dan mudah digunakan tanpa memerlukan peralatan yang mahal untuk mempersiapkannya. Tradisi pengobatan suatu masyarakat tidak lepas dari kaitan budaya setempat (Gain 2013). Pada penelitian ini jenis tumbuhan yang tergolong pengobatan ada delapan jenis yaitu Zingiber officinale, Zingiber purpureum, Zingiber americans, Curucuma domestica, Curcuma xanthoriza, Alpinia galanga, Kaempferia galanga, dan Amomum compactum.

Perawatan merupakan suatu proses yang berhubungan dengan pencegahan, perawatan dan manajemen penyakit dan juga proses stabilisasi mental, fisik dan rohani melalui pelayanan yang ditawarkan oleh organisasi, institusi dan unit profesional kedokteran (Pinzon dan Asanti 2010). Perawatan yang digunakan terkait dengan penelitian ini adalah perawatan pada ibu hamil, persalinan, pasca melahirkan, dan melancarkan ASI. Jenis tumbuhan yang digunakan adalah Zingiber purpureum dan Etlingera elatior.

Kesehatan merupakan salah satu kebutuhan dasar bagi keberlangsungan hidup manusia. Kebutuhan lainnya seperti pangan, tempat tinggal dan pendidikan, merupakan kebutuhan primer bagi kehidupan. Masyarakat mengenal dua jenis pengobatan untuk memperoleh kesehatan yang optimal yaitu, pengobatan modern (medis) dan pengobatan alternatif atau tradisional. Pengobatan medis merupakan jenis pengobatan yang menggunakan alat, cara, dan bahan yang bersifat modern dan berbahan kimia yang termasuk dalam standar pengobatan kedokteran modern. Sedangkan pengobatan alternatif merupakan suatu upaya kesehatan yang berakar pada tradisi dan menggunakan bahan alami yang sistem pengobatannya berbeda jauh dengan sistem pengobatan dalam bidang ilmu kedokteran (Ryadi 2016). Jenis yang digunakan untuk kelompok kesehatan adalah Zingiber officinale dan Zingiber purpureum yang memiliki potensi untuk menghangatkan tubuh dan meningkatkan stamina dan nafsu makan.

Ditinjau dari kandungan kimianya, menurut (Nasution 2009) jenis tumbuhan dari famili Zingiberaceae mengandung senyawa bioaktifantara lain minyak atsiri, saponin, flavonoid dan polifenol yang berkhasiat sebagai pengobatan. (Dewi et al. 2017) menyatakan bahwa jenis tumbuhan yang banyak dimanfaatkan sebagai obat di Desa Tolai Kecamatan Torue Kabupaten Parigimoutong adalah dari famili Zingiberaceae yang mengandung minyak atsiri dan resin, serta dalam obat-obatan suku ini digunakan sebagai karminatif, stimulans dan pemberi aroma atau bumbu.

Minyak atsiri merupakan senyawa bioaktif yang terdapat pada rimpang yang pada umumnya berfungsi sebagai aromaterapi. Aromaterapi memberikan efek menenangkan dan menyegarkan tubuh. Di beberapa jenis tumbuhan, minyak atsiri dapat digunakan sebagai bahan analgesik, antiseptik internal atau eksternal, stimulant untuk obat sakit perut, haemolitik atau sebagai enzimatik, sebagai sedatif, dan lain-lain. Minyak atsiri selain memiliki aroma yang harum juga bemanfaat untuk menteralisir bau badan dan membantu pencernaan dengan merangsang sistem saraf sekresi. Senyawa saponin dalam ilmu pengobatan dapat digunakan sebagai bahan antimikroba dan bahan racun. Flavonoid golongan fenol alam terbesar yang bekerja sebagai antioksidan untuk mengendalikan radikal bebas yang dapat menyebabkan tumor, dapat berfungsi sebagai antivirus dan antimikroorganisme. Senyawa polifenol bersifat antioksidan aktif yang berfungsi mencegah oksidasi LDL (Low Density Lipoprotein) dan kolesterol, sehingga dapat 
mencegah timbulnya penyait kronis. Selain itu juga berperan sebagai antimikroba dan dapat menurunkan kadar gula dalam darah (Sinaga dan Suprihatin 2011).

Perbedaan pemanfaatan jenis tumbuhan dapat dipengaruhi oleh proses modernisasi dan beberapa masalah seperti perubahan fungsi hutan karena tekanan ekonomi dan pertambahan penduduk (Ibo dan Arimukti 2019). Berdasarkan hasil penelitian diketahui bahwa fasilitas kesehatan modern di Desa Sipituihuta sudah tersedia namun masyarakat masih cendrung lebih mengutamakan pengobatan tradisional karena bahannya lebih aman dan murah serta banyak tersedia di pekarangan. Ditinjau dari segi ekonomi, adanya tumbuhan obat ini cukup membantu masyarakat untuk mendapatkan tambahan rupiah karena tanaman obat cukup laku di pasaran. Dalam memperbaiki masalah kesehatan tumbuhan obat juga sangat membantu masyarakat Desa Sipituhuta karena obat tidak akan merasakan efek samping dari ramuan herbal yang mereka buat, berbeda dengan masyarakat yang bergantung pada obat-obatan sintetik selain harga yang cukup tinggi juga memiliki efek samping yang mengkhawatirkan. Oleh karena itu, untuk menambah penghasilan keluarga, juga untuk melestarikan tradisi dan menghemat biaya berobat. Hal ini didukung oleh penelitian (Dewi et al. 2017) bahwa adanya tanaman obat ini cukup membantu masyarakat untuk tambahan pendapatan, karena tanaman obat cukup laku di pasaran dan sangat membantu masyarakat, tidak memiliki efek samping dari ramuan herbal dibanding dengan obat-obatan sintetik.

\section{SIMPULAN}

Masyarakat Etnis Batak Toba memanfaatkan sembilan jenis tumbuhan dari suku Zingiberaceae yaitu Zingiber officinale (jahe), Zingiber purpureum (bungle), Zingiber americans (leppuyang), Curucuma domestica (kunyit), Curcuma xanthorhiza (temulawak), Alpinia galanga (lengkuas), Kaempferia galanga (kencur), Etlingera elatior (kecombrang), dan Amomum compactum (kapulaga). Berdasarkan pemanfaatannya suku Zingiberaceae banyak dimanfaatkan sebagai bahan pengobatan, perawatan dan kesehatan.

\section{DAFTAR PUSTAKA}

Anggraeni R. 2016. Studi etnobotani masyarakat subetnis Batak Toba di Desa Peadungdung, Sumatera Utara, Indonesia. Pro-Life. 3(2):129-142.

BPS Humbang Hasundutan. 2018. Pertumbuhan Ekonomi Humbang Hasundutan. Sumut: Badan Pusat Statiskik.

Dewi NKL, Jamhari M, Isnainar I. 2017. Kajian pemanfaatan tanaman sebagai obat tradisional di Desa Tolai Kecamatan Torue Kabupaten Parigimoutong. EJIP BIOL. 5(2):92-108.
Gain R. 2013. Pengobatan Alternatif untuk Mengatasi Tekanan Darah. Jakarta: Gramedia Pustaka Utama.

Handayani A. 2015. Pemanfaatan tumbuhan berkhasiat obat oleh masyarakat sekitar Cagar Alam Gunung Simpang, Jawa Barat. Prosiding Seminar Nasional Masyarakat Biodiversitas Indonesia. 1(6):14251432.

Hutagalung MR. 2016. Pemanfaatan tumbuhan obat pada masyarakat Suku Batak Toba di Kampung Pagaran Lambung Kabupaten Tapanuli Utara, Sumatera Utara [skripsi]. Bogor: Institut Pertanian Bogor.

Ibo LK, Arimukti SD. 2019. Ethnobotanical study of Batak Toba sub-ethnic community in Martoba Village, Samosir District, North Sumatra. Prosiding Seminar Nasional Masyarakat Biodiversitas Indonesia. 5(2):234-241.

Kuntorini EM. 2018. Botani ekonomi suku Zingiberaceae sebagai obat tradisional oleh masyarakat di Kotamadya Banjarbaru. Bioscientiae. 2(1):25-36.

Nasution J. 2009. Oukup, ramuan tradisional Suku Karo untuk kesehatan pasca melahirkan: Suatu analisis bioprospeksi tumbuh-tumbuhan tropika Indonesia [tesis] Bogor: Institut Pertanian Bogor.

Pinzon R, Asanti L. 2010. Awas Stroke! Pengertian, Gejala, Tindakan, Perawatan dan Pencegahan. Yogyakarta: Penerbit Andi.

Purwanti R. 2016. Studi etnobotani pemanfaatan jenisjenis mangrove sebagai tumbuhan obat di Sulawesi. Proceeding of Mulawarman Pharmaceuticals Conferences. 3:340-348.

Ryadi ALS. 2016. Ilmu Kesehatan Masyarakat. Yogyakarta: Penerbit Andi.

Shanthi RV, Jumari, Izzati M. 2014. Studi etnobotani pengobatan tradisional untuk perawatan wanita di masyarakat Keraton Surakarta Hadiningrat. Biosaintifika: Journal of Biology \& Biology Education. 6(2):61-69.

Silalahi M, Supriatna J, Walujo EB, Nisyawati. 2013. Pengetahuan lokal dan keanekaragaman tumbuhan obat pada kelompok Sub Etnis Batak Karo di Sumatera Utara. Prosiding Seminar Nasional Bidiversitas dan Ekologi Tropika Indonesia (BioETI). Universitas Andalas Padang, 14 September 2013. Hal.146-153.

Sinaga E, Suprihatin WI. 2011. Perbandingan daya sitotoksik ekstrak rimpang 3 jenis tumbuhan Zingiberaceae terhadap sel kanker MCF-7. Jurnal Farmasi Indonesia. 5(3):125-133.

Susiarti S. 2015. Pengetahuan dan pemanfaatan tumbuhan obat masyarakat lokal di Pulau Seram, Maluku. Pros Sem Nas Masy Biodiv Indon. 1(5):1083-1087.

Walujo EB. 2011. Sumbangan ilmu etnobotani dalam memfasilitasi hubungan manusia dengan tumbuhan dan lingkungannya. Jurnal Biologi Indonesia. $7(2): 375-391$. 